\title{
Complicated COVID-19 pneumonia in an infant: A rare entity
}

\author{
Padmaja Biradar', Sushma Save², Murtuja Shaikh ${ }^{3}$ \\ From ${ }^{1}$ Resident Doctor, ${ }^{2}$ Professor (Additional), ${ }^{3}$ Assistant Professor, Department of Pediatrics, TN Medical College and BYL Nair Hospital, Mumbai \\ Central, Mumbai, India
}

\begin{abstract}
In the era of the COVID-19 pandemic, children are spared from severe disease, accounting for $0.39-12.3 \%$. According to a study in Wuhan China, only $2.7 \%$ of children are developed severe pneumonia. There are few cases reported with COVID-19 pneumonia in infants. We report the case of a 45-day-old infant who presented with respiratory distress with COVID-19 pneumonia required mechanical ventilation with an intercostal drainage tube for pyopneumothorax. The child was treated with intravenous antibiotics with supportive oxygen therapy. The fluid report of the pyopneumothorax was showing MRSA growth, so antibiotics were modified according to the sensitivity report. In this case report, COVID-19 pneumonia presented with complications in the form of pyopneumothorax with secondary bacterial infection and was successfully treated with a vigilant approach.
\end{abstract}

Key words: COVID-19 pneumonia, Infant, Intercostal drainage tube, MRSA infection, Pyopneumothorax

$\mathrm{I}$

$\mathrm{n}$ the era of the COVID-19 pandemic, children are spared from severe disease, accounting for $0.39-12.3 \%$ [1]. According to a study in Wuhan, China, only $2.7 \%$ of children have developed severe pneumonia [2]. There are very few cases reported with COVID-19 pneumonia in infants. Pyopneumothorax is a collection of air and pus in the pleural cavity. It is one of the complications of pneumonia.

Here, we report the case of a 45-day-old male infant with COVID-19 pneumonia who developed secondary bacterial infection with methicillin-resistant Staphylococcus aureus (MRSA) along with pyopneumothorax which was successfully treated.

\section{CASE REPORT}

A 45-day-old male infant, second by birth order, born of nonconsanguineous marriage presented with a complaint of fever for 7 days which was of moderate grade, on and off along with complaints of irritability and refusal to feed for 1 day, four episodes of vomiting in the last $24 \mathrm{~h}$, and difficulty in breathing for the last $12 \mathrm{~h}$. The infant was referred to our COVID-19 dedicated hospital in view of COVID-19 positive status (Fig. 1a).

The child was developmentally normal, unimmunized for age and was on formula feed. The child had a weight of $3.7 \mathrm{~kg}$ (between $-3 \mathrm{SD}$ and $-2 \mathrm{SD}$ ) and a length of $55 \mathrm{~cm}$ (between -2SD

\section{Access this article online}

Received - 25 May 2021

Initial Review - 10 June 2021

Accepted - 15 July 2021

DOI: $10.32677 /$ IJCR.2021.v07.i08.2966 to mean). The head circumference (HC) was $37 \mathrm{~cm}$ (between $3^{\text {rd }}$ to $50^{\text {th }}$ centile $)$ and the chest circumference was $34 \mathrm{~cm}(3 \mathrm{~cm}$ less than $\mathrm{HC}$ : normal for age). The child was conscious, irritable, and febrile (Temperature $38.2^{\circ} \mathrm{C}$ ) with a heart rate of 200 beats/ $\min (80-160$ beats/min), and tachypneic with a respiratory rate of $68 / \mathrm{min}(40-60 / \mathrm{min})$ with a severe grunt and respiratory distress. On auscultation, breath sounds were decreased bilaterally and more on the left side than the right side. Other systemic examinations were unremarkable. The child had a saturation of $70 \%$ on room air, required oxygen therapy despite of $100 \% \mathrm{FiO}_{2}$. The child could not maintain the saturation above $80 \%$ and had impending respiratory failure, so required mechanical ventilation. On mechanical ventilation with the maximum settings, there was no improvement (with $100 \% \mathrm{FiO}_{2}, \mathrm{SpO}_{2}$ of $90 \%$ ).

Post-intubation chest radiograph revealed a left-sided pneumothorax which required intercostal drainage (ICD) (Fig. 1b). An $80 \mathrm{ml}$ of seropurulent fluid with air (suggestive of pyopneumothorax) was drained. The child was started on intravenous fluids, injection Piperacillin and Tazobactam (100 mg/kg/dose TDS) along with injection Amikacin (15 mg/kg/ dose OD).

Post-ICD, the chest radiograph showed expansion of the left lung with evidence of consolidation in the left mid and lower zones and a left-sided pyopneumothorax. Clinical improvement was seen in the child. Investigations revealed hemoglobin of $10.2 \mathrm{gm} /$ $\mathrm{dL}$ and total leukocyte count was $15.2 \times 10^{9}$ cells/L and platelet count of $1.15 \times 10^{11}$ cells/L suggestive of thrombocytopenia

Correspondence to: Dr. Sushma Save, Ajmera AEON, 2002, North (B) Wing, Bhakti Park, Wadala (East) Mumbai - 400 037, India. E-mail: sushmasave73@gmail.com

(C) 2021 Creative Commons Attribution-NonCommercial 4.0 International License (CC BY-NC-ND 4.0). 
with anemia (Table 1). A high-resolution computed tomography (HRCT) thorax showed the left lower lobe atelectasis and lung volume loss with thick and enhancing pleural membrane suggestive of empyema (Fig. 2).

Repeat COVID-19 reverse-transcription polymerase chain reaction (RTPCR) swab of day eight of illness came negative. Antibiotics were escalated to injection Meropenem $(40 \mathrm{mg} / \mathrm{kg} / \mathrm{dose}$ 3 times a day) and injection Vancomycin $(15 \mathrm{mg} / \mathrm{kg} /$ dose 3 times a day) continued as per the sensitivity report and packed cell volume (PCV) transfusion in view of anemia. Culture pleural fluid grew MRSA which was sensitive to gentamicin, erythromycin, vancomycin, and linezolid. The pleural fluid cytology and culture/ sensitivity findings are shown in Table 2.

The child required mechanical ventilation for 3 days, then $\mathrm{O}_{2}$ by continuous positive airway pressure (CPAP) for 3 days followed by humidified $\mathrm{O} 2$ by nasal prongs for 11 days, and started on Ryles tube feeds with supplements. ICD removal was done after 11 days when drain output was nil for 24 hours with absent column movement in well-positioned ICD. The child received intravenous antibiotics for 14 days and then switched over to oral linezolid (10mg/kg/dose TDS) for 2 weeks. The child was stable, feeding well, hence discharged.

\section{DISCUSSION}

COVID-19 infection in infants and pediatric age group is usually mild to moderate with the vast majority percentage are

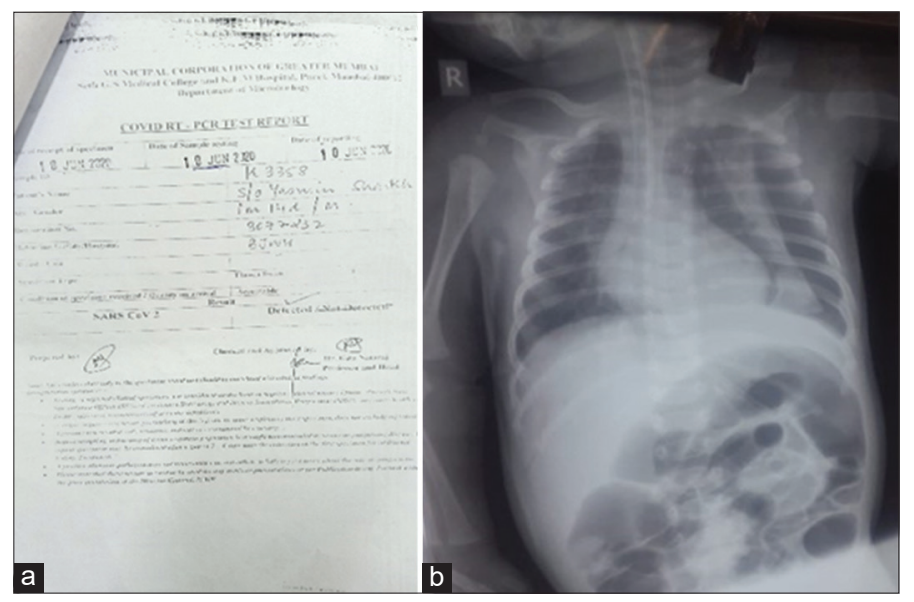

Figure 1: (a) RT-PCR report and (b) chest X-ray of the patient

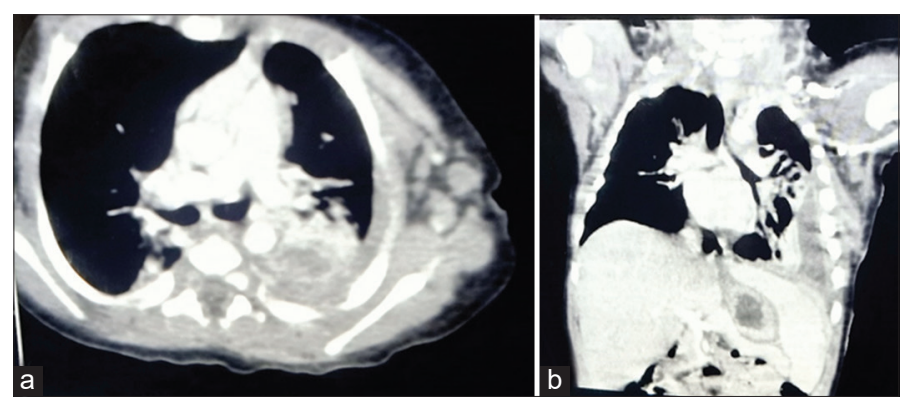

Figure 2: HRCT thorax showing the left lower lobe atelectasis and lung volume loss with thick and enhancing pleural membrane suggestive of empyema asymptomatic carriers [1]. The younger population has more severe COVID-19 pneumonia with secondary bacterial infection than aged children. According to a study in Wuhan, China, only $2.7 \%$ of children developed severe pneumonia [2]. In the meta-analysis of 24 studies, 3338 patients with COVID-19 were evaluated for acute bacterial infection. In those cases, bacterial co-infection (estimated on presentation) was identified only in $3.5 \%$ of patients and secondary bacterial infection in $14.3 \%$ of adult patients [3]. No such studies are available in the pediatric population.

In an infant with COVID-19 pneumonia, chances of bacterial co-infection cannot be ignored. In our case, the patient developed COVID-19 pneumonia with bacterial co-infection with MRSA which got further complicated to pyopneumothorax. Pyopneumothorax is a collection of pus and air in the pleural

Table 1: Hematological investigations of the patient

\begin{tabular}{|c|c|c|c|c|c|}
\hline Day of illness & Day 2 & Day 4 & Day 6 & Day 8 & Day 12 \\
\hline $\begin{array}{l}\text { Hemoglobin } \\
(10.5-14 \mathrm{~g} / \mathrm{dL})\end{array}$ & 10.2 & 9.2 & 8.1 & 11.8 & 11.5 \\
\hline $\begin{array}{l}\text { Total Leukocyte } \\
\text { Count }(6-14 \times \\
\left.10^{9} \text { cells } / \mathrm{L}\right)\end{array}$ & 15390 & 5300 & 3300 & 12000 & 11500 \\
\hline $\begin{array}{l}\text { Platelet }(1.5-4 \times \\
\left.10^{11} \text { cells } / \mathrm{L}\right)\end{array}$ & 115000 & 37000 & 77000 & 41000 & 1,44000 \\
\hline $\begin{array}{l}\text { BUN }(8-20 \mathrm{mg} / \\
\mathrm{dL}) / \text { Creatinine } \\
(0.5-1 \mathrm{mg} / \mathrm{dL})\end{array}$ & $9 / 0.23$ & $9 / 0.4$ & $7 / 0.4$ & $8 / 0.3$ & $07 / 0.4$ \\
\hline $\begin{array}{l}\mathrm{Na}^{+}(135- \\
145 \mathrm{mmol} / \mathrm{L}) / \\
\mathrm{K}^{+}(3.5-5 \mathrm{mmol} / \\
\mathrm{dL}) / \mathrm{Cl}^{-}(95-105 \\
\mathrm{mmol} / \mathrm{dL})\end{array}$ & $\begin{array}{c}136 / 5.7 / \\
103\end{array}$ & $\begin{array}{c}140 / 4.5 / \\
100\end{array}$ & $\begin{array}{c}142 / 4.2 / \\
103\end{array}$ & $\begin{array}{c}140 / 4.4 / \\
99\end{array}$ & $\begin{array}{c}138 / 4.0 / \\
100\end{array}$ \\
\hline $\begin{array}{l}\mathrm{SGOT}(8-40 \\
\mathrm{U} / \mathrm{L}) / \mathrm{SGPT}(8- \\
40 \mathrm{U} / \mathrm{L})\end{array}$ & $90 / 17$ & $27 / 11$ & $30 / 12$ & $40 / 18$ & $28 / 12$ \\
\hline $\begin{array}{l}\mathrm{Ca}^{2+}(8.5-10.2 \\
\mathrm{mg} / \mathrm{dL}) / \mathrm{PO}^{4-} \\
(4.5-6.5 \mathrm{mg} / \mathrm{dL})\end{array}$ & $9.3 / 5.6$ & - & - & $8.9 / 5.5$ & $8.8 / 5.2$ \\
\hline $\begin{array}{l}\text { Total Protein } \\
(6-7 \mathrm{~g} / \mathrm{dL}) / \\
\text { Albumin } \\
(3.5-5 \mathrm{~g} / \mathrm{dL})\end{array}$ & $4.7 / 3.1$ & $3.2 / 2$ & $4.2 / 2.2$ & - & $4 / 2.3$ \\
\hline $\begin{array}{l}\text { Alkaline } \\
\text { Phosphatase } \\
(40-129 \mathrm{U} / \mathrm{L})\end{array}$ & 229 & 147 & - & - & 342 \\
\hline $\begin{array}{l}\text { C Reactive } \\
\text { Protein - } \\
5 \mathrm{mg} / \mathrm{L})\end{array}$ & 100 & 247 & 104 & - & - \\
\hline
\end{tabular}

Table 2: Pleural fluid cytology and culture/sensitivity

\begin{tabular}{ll}
\hline Pleural fluid & 450 cells $/ \mathrm{ml}, 67 \%$ polymorph, and $33 \%$ \\
and routine & lymphocyte with degenerated WBC with \\
microscopy & plenty of degenerated RBC in background \\
Pleural fluid & MRSA sensitive to Gentamicin, \\
culture and & Erythromycin, Vancomycin, and \\
sensitivity & Linezolid. Resistant to Ciprofloxacin, \\
& Penicillin, and Cotrimoxazole.
\end{tabular}


cavity [4,5]. Acute pyopneumothorax is a known complication of staphylococcal infection in adults but very few cases were reported in the infantile age group with confirmatory microbiological evidence [6].

Various mechanisms were put forward in case of COVID19 pneumonia with secondary bacterial infections. Some of these include respiratory epithelial damage making it more susceptible to secondary bacterial infection. Other possibilities of pyopneumothorax can be the iatrogenic cause, secondary to positive pressure ventilation. A very few case reports are documented and proven of pyopneumothorax in infants which are successfully treated [6-8]. Complicated COVID 19 pneumonia is seen in adults with an incidence of $0.91 \%$ but no incidence as such is given in the pediatric population [9]. A case report of a 4-year-old child with similar complaints of pyopneumothorax on diagnosis was managed similarly with an intercostal drainage tube and intravenous antibiotics [10]. To the best of our knowledge, this is the first case report with COVID-19 pneumonia with bacterial co-infection with MRSA with pyopneumothorax.

\section{CONCLUSION}

Even though the majority of COVID-19 infections are mild to moderate in infants, we should be vigilant about the progression to severe pneumonia. Even the rarest complication should be kept in mind while treating. In case of severe pneumonia, broad-spectrum antibiotics are warranted at first which can be further de-escalated according to microbiological culture and sensitivity report.

\section{REFERENCES}

1. Ciuca IM. COVID-19 in children: An ample review. Risk Manage Healthc Policy 2020;2020:661.

2. Liu W, Zhang Q, Chen J, Xiang R, Song H, Shu S, et al. Detection of covid-19 in children in early January 2020 in Wuhan, China. N Engl J Med 2020;382:1370-1.

3. Langford BJ, So M, Raybardhan S, Leung V, Westwood D, MacFadden DR, et al. Bacterial co-infection and secondary infection in patients with COVID-19: A living rapid review and meta-analysis. Clin Microbiol Infect 2020;26:1622-9.

4. Gupta A, Dutt N, Patel N. The different treatmentmodalities of pyopneumothorax-a study of 50 cases. IntJ Med Sci Public Health 2013;2:609-12

5. Samovsky M, Loberant N, Lemer J, Altman E. Tension pyopneumothorax. Clin Imaging 2005;29:437-8.

6. Johnson FE. PyopneumothoraxIn infants: A report of ten cases complicating pneumonia. Am J Dis Child 1927;33:740-56.

7. Rogatz JL, Rosenberg A. Acute pyopneumothorax: A case in an infant aged nine weeks. Am J Dis Child 1931;41:1104-10.

8. Gairdner P. Staphylococcal pyopneumothorax in an infant: Recovery. $\mathrm{Br}$ Med J 1944;1:44-5.

9. Martinelli AW, Ingle T, Newman J, Nadeem I, Jackson K, Lane ND, et al. COVID-19 and pneumothorax: A multicentre retrospective case series. Eur Respir J 2020;56:2002697.

10. Ijezie E, Ekpe EE. Tension pyopneumothorax in an immune-competent child in Uyo, Nigeria: A case report. Int J Contemp Pediatr 2015;2:474-7.

Funding: None; Conflicts of Interest: None Stated.

How to cite this article: Biradar P, Save S, Shaikh M. Complicated COVID-19 pneumonia in an infant: A rare entity. Indian J Case Reports. 2021;7(8):333-335. 